\title{
Leadership Styles for Employee Empowerment: Malaysian Retail Industry
}

\author{
Md Asadul Islam \\ Faculty of Economics and Management, Universiti Putra Malaysia (UPM), Malaysia \\ Amer Hamzah Jantan, PhD (Corresponding Author) \\ Faculty of Economics and Management, Universiti Putra Malaysia (UPM), Malaysia \\ Email: amerhamzah@upm.edu.my
}

Md Adnan Rahman

Putra Business School, Universiti Putra Malaysia (UPM), Malaysia

Abu Bakar A. Hamid, PhD

Putra Business School, Universiti Putra Malaysia (UPM), Malaysia

Fariha Binte Mahmud

Jahangirnagar University (JU), Bangladesh

Ashikul Hoque

Putra Business School, Universiti Putra Malaysia (UPM), Malaysia

Received: August 23, 2018

doi:10.5296/jmr.v10i4.13568
Accepted: Sep 13, $2018 \quad$ Published: October 1, 2018

URL: https://doi.org/10.5296/jmr.v10i4.13568

\begin{abstract}
The aim of this paper is to examine the impact of the different leadership styles on employee empowerment in the Malaysian retail industry. A quantitative study was carried out to collect
\end{abstract}




\section{Macrothink}

Journal of Management Research

ISSN 1941-899X 2018, Vol. 10, No. 4

and analyse the data. A survey was conducted through the convenience sampling to include one hundred respondents, who are working in retail organizations in Selangor, Malaysia. The personal data of the respondents were analysed through descriptive analysis. In addition, the inferential analysis was employed to test the hypotheses. The results of the study found that two of the three hypotheses were supported by respondents while another one was rejected. The paper includes research limitations and direction for future research.

Keywords: Leadership, Style, Retail Industry, Empowerment, Malaysia. 


\section{Introduction}

Different leadership styles have different kinds of outcomes withdirect or indirect effect on the employee behaviour and attitude within the organisations. Previous studies have established that the transformational leadership style has been effective for the employee performance, engagement, and retention within the companies, while the transactional leadership style has the negative influence on the employee and organizational long-term performance. The transformational leadership style has a positive impact on employee creativity, motivation, self-efficacy, and organisational performance (Gong, Huang, \& Farh, 2009; Bronkhorst et al., 2015; Newland, Newton, Podlog, Legg, \& Tanner, 2015; Bronkhorst, Steijn, \& Vermeeren, 2015; Vasilagos, Polychroniou, \& Maroudas, 2017; Kark, Van Dijk, \& Vashdi, 2018).

In addition, the transactional leadership style in previous studies has been found to enhance job satisfaction compared with transformational leadership (Epitropaki \& Martin, 2005; LePine, Zhang, Crawford, \& Rich, 2015; Boamah, Laschinger, Wong, \& Clarke, 2018). Transformational leaders help individuals adopt the organisational change in a competitive and challenging situation (Bommer, Rubin, \& Baldwin, 2004; Vasilagos et al., 2017; Kark, et al., 2018). Hence, both transactional and transformational leadership styles have an impact on the employees and organisations, but in different ways. In addition, the laissez-faire leadership style has been found as the least effective leadership style, which has a negative impact on employees or the followers' performance and productivity (Bass \& Avolio, 1985; Yahya \& Ebrahim, 2016). However, throughout the previous studies, it has not been clear how these leadership styles impacted on employee empowerment; this being the process of giving employees a certain degree of autonomy and responsibility for decision-making regarding their specific organisational tasks so that they can perform them in the right way and on time.

Numerous studies have examined the prerequisites of employee empowerment in different industries within the context of various countries (Yang \& Choi, 2009; Zhu, Sosik, Riggio, \& Yang, 2012; Yusoff, Imran, Qureshi, \& Kazi, 2016). Thus, in respect of the cultural disparity between the west and other countries, no study so far has been conducted in the Malaysian retail industry.

Malaysia is an emerging country with a strong and attractive retail industry where world-recognised retailers such as Tesco, M\&S, ZARA, and GAP have now successfully opened their branches (Star Online, 2017; Ismail, 2017; and Kanter, 2018;). The Malaysian retail industry postures a growing trend with the number of tourists projected to grow from 26 million to 36 million by 2020 , while the local number of retail customers will also substantially increase (Ismail, 2017; Murugiah 2018). Therefore, it is crucial for employers to make sure that the managers adopt the right leadership style for their employees and organisational performance development. Here, many previous studies have found that the employees perform better when they are empowered (Zorn \& Violanti, 1993; Meyerson \& Dewettinck, 2012; Kariuki \& Murimi, 2015; Yusoff, et al., 2016; Kohli \& Sharma, 2017; Oloko \& Ogutu, 2017; Bose, 2018; Baird, Su, \& Munir, 2018). However, the impact of 
leadership styles has not yet been disclosed as specifically suitable or effective for employee empowerment.

Thus, the objective of this study is to specifically identify the leadership style which has greater benefit with the least effect on employee empowerment in the Malaysian retail industry. By examining the impact of the three leadership styles - transactional, transformational and laissez-faire - we aim to help organisations and managers to adopt the right leadership style so that they can empower and benefit their employees, as well as the organisation. Moreover, findings from this study will lay the groundwork for future research that may affect other worldwide industries.

\section{Literature Review}

\subsection{Leadership Styles}

\subsubsection{Transformational Leadership Style}

Transformational leaders work with followers, employees or teams to identify the necessary changes and create a vision. Their role is to guide them through the changes by motivating and executing the changes in tandem with the committed members of the different groups (Zhu, Sosik, Riggio, \& Yang, 2012; Rosenbach, 2018; and Northouse, 2018). Hence, this leadership style is identified as the visionary leadership where managers in the organisations inspire their employees to exceed certain expectations (Doucet, Fredette, Simard, \& Tremblay, 2015). A leader with the transformational leadership style is more of a charismatic leader and attempts to motivate employees both through his vision and charisma. Burns (1978) introduced the concept of transformational leadership where he identified that transformational leaders help employees modify their beliefs and attitudes but by way of an inspirational process, setting particular integrated goals that motivate employees to achieve them through their combined efforts. The transformational leaders work with employees to ensure that the goals and missions of the companies are presented clearly amongst employees (Avolio, Walumbwa, \& Weber, 2009; Daft, 2014; and Tajasom, Hung, Nikbin, and Hyun, 2015). Here, these leaders with their unique beliefs, values, behaviours and attitudes encourage their followers. Therefore, they motivate the employees in such a particular way that mainly goes beyond the exchanges and rewards and finally creates an emotional attachment for the followers or employees towards the leaders. According to Barbuto (1997), the employees trust the transformational leaders and they try to fulfil the expectations of the leaders.

\subsubsection{Transactional Leadership Style}

Transactional leadership style focuses on the supervision and organisation of the workers in the organizations. Moreover, it also focuses on the individual and organisational performance in the organizations. Hence, the leaders or managers using this leadership style apply rewards to gain desired performance from every employee and the entire team. Moreover, they also use punishment if the employees do not perform according to expectation or if they find any differences in the performance process through the supervision (Bass, 1997; Pieterse, et al., 2010). Transactional leadership only helps employees when they need more achievement 
than the regular achievements. Therefore, they use the carrot and stick approach to attain the respective purposes (Spreitzer, 1995; Bass, 1997; Pieterse, et al., 2010). Employees are given rewards only when they execute certain tasks accordingly or are punished if the completion of their functions is not achieved (Pieterse, Van Knippenberg, Schippers, \& Stam, 2010; Zhu, et al., 2012; Ma \& Jiang, 2018; Northouse, 2018). Since the transactional leaders are mainly concerned about completing tasks, they apply both negative and positive reinforcements according to the situations and need so that they can to gainthe targets or results, which are desired, both of which have positive and negative impacts on the employees (Ma \& Jiang, 2018; Northouse, 2018). Transactional leaders do not give right an employee in the companies to be an innovative employee in terms of performing functions or duties in the organisation (Hartog \& Van Muijen, 1997; Pieterse, et al., 2010; Zhu, et al., 2012; and Rosenbach, 2018).

Smith, Eldridge, and DeJoy (2016) outlined the two dimensions of the corrective approach used by the transactional leaders. These dimensions are Management by Exception (MBE) and contingent reward. These become either active or passive (Smith et al, 2016). In this regard, contingent reward refers to the rewards so that the organizations can gain the best results from employees working in different positions, teams and divisions. With MBE, leaders mainly use the corrective action when they identified processes of works or operations are not continuing properly. The corrective actions are divided into two ways MBE passive and MBE active. Active MBE suggests that leaders encourage the anticipation behaviour. The transactional leader tries to bring a solution to the potential problem when the leader foresee a problem might occur. On the other hand, in MBE passive, the transactional leaders do not predict a potential problem, however, they act only after the problems occur.

According to the research results conducted by Appelbaum, Karasek, Lapointe \& Quelch, (2015), transactional leadership cannot be discounted as the research shows that the propoer mixture of the incentives and rewards, connected with a certain organisational culture, can raise empowerment among certain types of employees. In addition, Ma \& Jiang (2018) found in their research that transactional leadership is positively related to creative behaviours of followers or employees, however, the creative behaviour usually arises from employee empowerment (Oldham \& Cummings, 1996; Yang \& Ok Choi, 2009).

\subsubsection{Laissez Faire Leadership Style}

A leader with this style of leadership avoids making decisions. They are usually reluctant to act and avoid situations in which there are chances to encounter problems (Daft, 2014; Northouse, 2018). Leaders who adopt the laissez-faire leadership style do not provide feedback to their followers and therefore, they work according to their own process of being naturally empowered (Skogstad, Aasland, Nielsen, Hetland, Matthiesen, \& Einarsen, 2015; and Northouse, 2018). They do not use rewards or other tools to satisfy the needs of their followers (Avolio, Walumbwa, \& Weber, 2009; Daft, 2014). However, they give full power to the followers to accomplish the duties according to the instruction of the organisations (Frischer, 2006; Yang, 2015; Humborstad, Nerstad, \& Dysvik, 2014; Wong, \& Giessner, 2018). 


\subsection{Empowerment}

Employee empowerment has been a topic of discussion for many years within academic research and it has been identified as the most effective process for organisations to get the best outcome from their employees (Spreitzer, 1995; Kariuki, \& Murimi, 2015; Kar, 2017). According to Pearson \& Moomaw (2005), empowerment is a strategic management option for managers in companies to encourage employees to work beyond the norm and accomplish jobs in a flexible manner. On the other hand, empowerment has been acknowledged as the process of stimulating employees to be engaged in the workplace (Meyerson \& Dewettinck 2012; Kohli \& Sharma, 2017; and Northouse, 2018). It is because the employees are given the power to make decisions and become innovative so that certain types of functions can be carried out (Spreitzer, 1995; Choi, Goh, Adam, \& Tan, 2016; Kar, 2017). However, in many cases, employee empowerment may be counterproductive to an organisation because the implementation of empowerment practices outlines that a certain amount of autonomy and authority is given to employees and they are trusted (Cecez-Kecmanovic \& Janson, 2009; Öqvist, 2010). As a result, some employees may become overconfident in the workplace which may lead to lower performance and an associated impact on management, as they may lose control over certain employees (Spreitzer \& Doneson, 2005; Lewis, 2018). For example, employee empowerment practices might be detrimental for companies if the employees do not abide by corporate information and management procedures.

\subsection{Hypotheses}

In light of the reviewed literature and research objectives, the following hypotheses have been created for the investigation of this study:

$\mathbf{H}_{1}$ : The transformational leadership style has a positive relationship with employee empowerment in the retail industry of Malaysia.

$\mathbf{H}_{2}$ : The transactional leadership style has a positive relationship with employee empowerment in the retail industry of Malaysia.

$\mathbf{H}_{3}$ : The laissez-faire leadership style has a positive relationship with employee empowerment in the retail industry of Malaysia.

\section{Methodology}

Employees from retail companies in Selangor in Malaysia were utilised as the population for this study. Selangor was selected because there are many shopping centres in the area, as well as many local and foreign workers living their; therefore, it was easier for the researchers to conduct the survey. The questionnaire contained twenty items of four variables: employee empowerment, transformational leadership style, transactional leadership style, and the laissez-faire leadership style. All were measured using a five-point Likert scale. The questionnaire was pre-tested before we distributed it among the participants. 112 questionnaires were distributed based on convenience sampling with closed-ended questions and 100 useable questionnaires were returned while respect of the questionnaires were incomplete. The respondents in the survey were employees from retail organizations. 


\section{Macrothink}

The survey questionnaire for this study was created from Bass's (1985) theory of transformational and transactional leadership, while some items were also collected from the theories of Spreitzer (1995); Spreitzer \& Doneson (2005); Frischer, J. (2006); Skogstad et al., (2015); Yang (2015); and Islam, Jantan, Wei, Abdullah, and Manirajah (2018). The Pearson's Correlation coefficient has been used to determine the relationships between the variables to test the hypotheses. If the relationship between the independent and dependent variable is high the impact of the independent variable on the dependent variable will be high. Again, if the relationship between the independent and dependent variable is low the impact of the independent variable on the dependent variable will be low. There are three independent variables in this study: the transformational leadership style, the transactional leadership style and the laissez-faire leadership style, which impacts on the dependent variable - being employee empowerment.

\section{Results and Discussion}

\subsection{Demographic Profiles of Respondents}

The demographic profiles of the respondents have been outlined in Table 1. In this study, the statistical data of the respondents has been included in relation to age, gender, marital status, ethnicity, educational level and work experience.

Table 1. Demographic Profile of the Respondents

\begin{tabular}{|c|c|c|}
\hline Variables & Values & $\%$ \\
\hline \multirow{4}{*}{ Age } & Below 20 & \\
\hline & $21-30$ & \\
\hline & $31-40$ & \\
\hline & Above 40 & \\
\hline \multirow[t]{2}{*}{ Gender } & Male & \\
\hline & Female & \\
\hline \multirow[b]{2}{*}{ Marital Status } & Single & \\
\hline & Married & \\
\hline \multirow{3}{*}{ Ethnicity } & Malay & \\
\hline & Chinese & \\
\hline & Others & \\
\hline \multirow{4}{*}{ Education level } & High School & \\
\hline & Undergraduate & \\
\hline & Masters/MBA & \\
\hline & MPhil/DBA/PhD & \\
\hline \multirow{4}{*}{ Work experience } & 1 to 2 years & \\
\hline & 3 Year to 5 years & \\
\hline & 6 Years to 10 years & \\
\hline & Above 10 years & \\
\hline
\end{tabular}




\section{1) Macrothink}

\subsection{Reliability Test}

A reliability test has also been conducted to ensure consistency and measure the results considering the value of Cronbach's Alpha. A Cronbach's Alpha coefficient value of 0.70 is an acceptable reliability score (Nunnally and Bernstein, 1994). In this regard, if the value of Cronbach's Alpha is closer to 1.0 the higher value will be an indication of the internal consistency, which outlines that the respective variable is highly inter-related. According to the results of the reliability test for this study presented in Table 2, the values of Cronbach's Alpha varied between 0.762 and 0.842 . It indicates that the scales used in this research are consistent and reliable.

Table 2. Reliability Table

\begin{tabular}{|l|c|c|}
\hline \multicolumn{1}{|c|}{ Variables } & Items & Cronbach's Alpha \\
\hline Transformational leadership & 5 & 0.842 \\
\hline Transactional leadership & 5 & 0.820 \\
\hline Laissez-faire leadership & 5 & 0.762 \\
\hline Employee empowerment & 5 & 0.782 \\
\hline
\end{tabular}

\subsection{Pearson Correlation Analysis}

The relationships between the independent variables and the dependent variables have been presented in Table 3. According to the results, through the Pearson's Correlation test, we can identify the level of relationships between all the independent variables and dependent variables with regard to the retail industry in Malaysia. The level of the relationship is determined based on the Rule of Thumb presented in Appendix 1. 
Table 3. Results of Pearson's Correlation Test

\begin{tabular}{l|c|c|c|c|}
\hline \multicolumn{1}{c|}{ Variables } & $\begin{array}{c}\text { Employee } \\
\text { Empowerment }\end{array}$ & $\begin{array}{c}\text { Transformational } \\
\text { Leadership }\end{array}$ & $\begin{array}{c}\text { Transactional } \\
\text { Leadership }\end{array}$ & $\begin{array}{c}\text { Laissez-faire } \\
\text { Leadership }\end{array}$ \\
\hline $\begin{array}{l}\text { Employee } \\
\text { Empowerment }\end{array}$ & 1 & $0.853(* *)$ & $0.461(* *)$ & $0.745(* *)$ \\
$\begin{array}{l}\text { Transformational } \\
\text { Leadership }\end{array}$ & $0.853(* *)$ & 1 & & \\
$\begin{array}{l}\text { Transactional } \\
\text { Leadership }\end{array}$ & $0.461(* *)$ & & 1 & \\
$\begin{array}{l}\text { Laissez-faire } \\
\text { Leadership }\end{array}$ & $0.745(* *)$ & & 1 \\
\hline
\end{tabular}

Hypothesis 1:The transformational leadership style has a positive relationship with employee empowerment in the retail industry of Malaysia.

The resulting p-value of 0.0001 outlines that the transformational leadership style is significantly related to employee empowerment in the Malaysian retail industry context. It is because if the p-value is below $0.05(\mathrm{p}<0.05)$ it is actually an indication of the significant relationship between the independent and dependant variables. According to Table 4, a positive Pearson Correlation r-value of 0.853 shows that the transformational leadership style is positively related to employee empowerment based on the Guildford's Rule of Thumb. An r-value of 0.853 is an indication of the high correlation between the transformational leadership style and employee empowerment.

Thus, Hypothesis 1 is successfully supported according to the Rule of Thumb. This result is backed by the research carried out by Spreitzer, G. M. (1995); Petter et al., (2002); Kohli \& Sharma (2017); Islam et al., (2018); and Kark et al., (2018) where they found that if employees are given certain responsibilities and the ability to work with managers or leaders, they feel empowered. On the other hand, this finding is also supported by, and is consistent with, the results from the research works of Yang \& Ok Choi (2009); Daft (2014); Choi et al., (2016); and Boamah et al., (2018) where they also found the transformational leadership style very effective for employee empowerment.

Hypothesis 2: The transactional leadership style has a positive relationship with employee empowerment in the retail industry of Malaysia.

The resulting p-value of 0.0001 outlined that transactional leadership is not significantly related to employee empowerment in the Malaysian retail industry context. It is because if the p-value is above $0.05(0.05<\mathrm{p})$ it is actually an indication of the lower relationship between the independent and dependant variables. According to Table 4, a lower Pearson Correlation r-value of 0.461 shows that the transactional leadership style is negatively related to 
employee empowerment based on the Guildford's Rule of Thumb. An r-value of 0.461 is an indication of a lower or negative correlation between the transactional style and employee empowerment.

Thus, Hypothesis 2 is rejected according to the Rule of Thumb. This result is also supported by previous research where the researchers found that the transactional leaders did not provide autonomy to the employees which reduced employee empowerment (Hartog \& Van Muijen, 1997; Pieterse et al., 2010; Sosik, Riggio, \& Yang, 2012; Smith, et al, 2016; Kark et al., 2018. However, it is inconsistent with the results from the research works of Ma \& Jiang (2018) because they found the transactional leadership style sometimes empowered the employees to perform better within their organisations.

Hypothesis 3:The laissez-faire leadership style has a positive relationship with employee empowerment in the retail industry of Malaysia.

The p-value result of 0.0001 outlined that the laissez-faire leadership style is significantly related to employee empowerment in the Malaysian retail industry context. It is because if the p-value below $0.05(p<0.05)$ it is actually an indication of the significant relationship between the independent and dependant variables. According to Table 4, a positive Pearson Correlation r-value of $0.745(* *)$ shows that the laissez-faire leadership style is positively related to employee empowerment based on the Guildford's Rule of Thumb. An r-value of $0.745(* *)$ is an indication of a high correlation between the laissez-faire leadership style and employee empowerment. Thus, Hypothesis 3 is successfully supported according to the Rule of Thumb. This is supported by the findings of Skogstad et al, (2015); Frischer, (2006); and Yang, (2015) in that the laissez-faire leadership style has a significant relationship with employee empowerment within the organisations. This finding, which is also supported by Humborstad et al., (2014) and Wong \& Giessner, (2018), shows that the laissez-faire leadership style has a positive effect on employee empowerment.

\section{Conclusion}

The main objective of the study was to investigate which leadership style had a greater impact on employee empowerment in the Malaysian retail industry. The results illustrate that the transformational leadership style and the laissez-faire leadership style have a positive relationship with employee empowerment in the retail industry of Malaysia. However, transformational leadership has been identified as having the greater impact on employee empowerment rather than the laissez-faire leadership style, according to the correlation results. On the other hand, the transactional leadership style has a negative impact on employee empowerment. Hence, the findings of the study have shed light on what leadership style should be adopted by managers or leaders within organisations to empower their employees. The employers, managers and other decision makers can make the best decision in adopting the leadership style for employee empowerment.

\section{Limitation of the Study and Direction for Future Research}

There are some limitations of the study. The sample size of the study is limited to only one hundred respondents, which could be increased. In addition, the study includes only three 
independent variables and one dependent variable which could also be increased in any future research works for the development of the generalisation of the findings. Moreover, the future studies could be carried out through the use of a qualitative approach to gain in-depth results relating to leadership style and employee empowerment.

\section{References}

Avolio, B. J., Walumbwa, F. O., \& Weber, T. J. 2009. Leadership: Current theories, research, and future directions. Annual Review of Psychology, 60, 421-449. https://doi.org/10.1146/annurev.psych.60.110707.163621

Bose, I. (2018). Employee Empowerment and Employee Performance: An Empirical Study on Selected Banks in UAE. Journal of Applied Management and Investments, 7(2), 71-82.

Boamah, S. A., Laschinger, H. K. S., Wong, C., \& Clarke, S. (2018). Effect of transformational leadership on job satisfaction and patient safety outcomes. Nursing outlook, 6(2), 180-189. https://doi.org/10.1016/j.outlook.2017.10.004

Baird, K., Su, S., \& Munir, R. (2018). The relationship between the enabling use of controls, employee empowerment, and performance. Personnel Review, 7(1), 257-274. https://doi.org/10.1108/PR-12-2016-0324

Cecez-Kecmanovic, D., \& Janson, M. (2009). The notion of lifeworld applied to information systems research.

Choi, S. L., Goh, C. F., Adam, M. B. H., \& Tan, O. K. (2016). Transformational leadership, empowerment, and job satisfaction: the mediating role of employee empowerment. Human resources for health, 14(1), 73. https://doi.org/10.1186/s12960-016-0171-2

Daft, R. L. (2014). The leadership experience. Cengage Learning.

Dhillon, M. (2008). Determinants and Dimensions of Employee Empowerment: Revisiting the Literature.

Frischer, J. (2006). Laissez-faire leadership versus empowering leadership in new product developing. Danish Centre for Philosophy and Science Studies Aalborg University Fibigerstraede, (10).

Gong, Y., Huang, J. C., \& Farh, J. L. (2009). Employee learning orientation, transformational leadership, and employee creativity: The mediating role of employee creative self-efficacy. Academy of management Journal, 52(4), 765-778. https://doi.org/10.5465/amj.2009.43670890

Humborstad, S., I W., Nerstad, C. G. L., \& Dysvik, A. 2014. Empowering leadership, employee goal orientations and work performance: A competing hypothesis approach. Personnel Review, 43: 246-271. https://doi.org/10.1108/PR-01-2012-0008

Islam, M., A., Jantan, A., H., Wei, C., W., Abdullah, H. H., Manirajah, M. (2018). Factors Influencing Female Progression in Leadership Positions in the Ready-Made Garment (RMG) Industry in Bangladesh. Journal of International Business and Management, 1(1), 1-13. 
Ismail, L., (2018) Malaysia ranked 3rd in 2017 Global Retail Development Index. [Online] Available:

https://www.nst.com.my/business/2017/06/245956/malaysia-ranked-3rd-2017-global-retail-d evelopment-index. (July 08, 2018).

Kar, D. P. (2017). Development and implementation of an employee empowerment plan for sustainable competitive advantage. ACADEMICIA: An International Multidisciplinary Research Journal, 7(5), 15-22. https://doi.org/10.5958/2249-7137.2017.00048.9

Kark, R., Van Dijk, D., \& Vashdi, D. R. (2018). Motivated or Demotivated to Be Creative: The Role of Self-Regulatory Focus in Transformational and Transactional Leadership Processes. Applied Psychology, 67(1), 186-224. https://doi.org/10.1111/apps.12122

Kariuki, A., \& Murimi, C. (2015). Employee Empowerment and Organization Performance of Tata Chemicals Magadi Ltd, Kenya.

Kohli, A., \& Sharma, A. (2017). An analysis of employee empowerment and job satisfaction: a review. Management Dynamics, 17(1).

Lewis, D. R. (2018). The perils of overconfidence: Why many consumers fail to seek advice when they really should. Journal of Financial Services Marketing, 23(2), 104-111. https://doi.org/10.1057/s41264-018-0048-7

Ma, X., \& Jiang, W. (2018). Transformational Leadership, Transactional Leadership, and Employee Creativity in Entrepreneurial Firms. The Journal of Applied Behavioral Science, 0021886318764346. https://doi.org/10.1177\%2F0021886318764346

Meyerson, G., \& Dewettinck, B. (2012). Effect of empowerment on employees performance. Advanced Research in Economic and Management Sciences, 2(1), 40-46.

Murugiah, S., (2018) Malaysia retail industry grew 2.6\% in 1Q2018. [Online] Available: http://www.theedgemarkets.com/article/malaysia-retail-industry-grew-26-1q2018 (July 17, 2018).

Northouse, P. G. (2018). Leadership: Theory and practice. Sage publications.

Pieterse, A. N., Van Knippenberg, D., Schippers, M., \& Stam, D. (2010). Transformational and transactional leadership and innovative behavior: The moderating role of psychological empowerment. Journal of organizational behavior, 31(4), 609-623. https://doi.org/10.1002/job.650

Oldham, G. R., \& Cummings, A. (1996). Employee creativity: Personal and contextual factors at work. Academy of Management Journal, 39(3), 607-634. https://doi.org/10.5465/256657

Oloko, M., \& Ogutu, M. (2017). Influence of power distance on employee empowerment and MNC performance: A study of multinational corporations in Kenya.

Öqvist, K. L. (2010). The art of alchemy. Information Security Technical Report, 15(2), 47-50. https://doi.org/10.1016/j.istr.2010.09.003 
Pearson, L. C., \& Moomaw, W. (2005). The relationship between teacher autonomy and stress, work satisfaction, empowerment, and professionalism. Educational research quarterly, 29(1), 38-54.

Petter, J., Byrnes, P., Choi, D. L., Fegan, F., \& Miller, R. (2002). Dimensions and patterns in employee empowerment: Assessing what matters to street-level bureaucrats. Journal of Public Administration Research and Theory, 12(3), 377-400.

Rosenbach, W. E. (2018). Contemporary issues in leadership. Routledge.

Skogstad, A., Aasland, M. S., Nielsen, M. B., Hetland, J., Matthiesen, S. B., \& Einarsen, S. (2015). The relative effects of constructive, laissez-faire, and tyrannical leadership on subordinate job satisfaction. Zeitschrift für Psychologie. https://doi.org/10.1027/2151-2604/a000189

Spreitzer, G. M. (1995). Psychological empowerment in the workplace: Dimensions, measurement, and validation. Academy of management Journal,38(5), 1442-1465. https://doi.org/10.5465/256865

Spreitzer, G. M., \& Doneson, D. (2005). Musings on the past and future of employee empowerment. Handbook of Organizational Development. Thousand Oaks: Sage, 311-324.

Star Online, (2018) Malaysia is best retail market worldwide after China, India. [Online] Available:

https:/www.thestar.com.my/business/business-news/2017/06/05/malaysia-is-best-retail-mark et-worldwide-after-china-and-india/. (July 27, 2018).

Vasilagos, T., Polychroniou, P., \& Maroudas, L. (2017). Relationship Between Supervisor's Emotional Intelligence and Transformational Leadership in Hotel Organizations. In Strategic Innovative Marketing (pp. 91-95). Springer, Cham. https://doi.org/10.1007/978-3-319-56288-9

Wong, S. I., \& Giessner, S. R. (2018). The thin line between empowering and laissez-faire leadership: An expectancy-match perspective. Journal of Management, 44(2), 757-783. https://doi.org/10.1177\%2F0149206315574597

Yang, S. B., \& Ok Choi, S. (2009). Employee empowerment and team performance: Autonomy, responsibility, information, and creativity. Team Performance Management: An International Journal, 15(5/6), 289-301. https://doi.org/10.1108/13527590910983549

Yang, I. (2015). Positive effects of laissez-faire leadership: conceptual exploration. Journal of Management Development, 34(10), 1246-1261. https://doi.org/10.1108/JMD-02-2015-0016

Yusoff, R. B. M., Imran, A., Qureshi, M. I., \& Kazi, A. G. (2016). Investigating the relationship of employee empowerment and sustainable manufacturing performance. International Review of Management and Marketing, 6(4S), 284-290. 


\section{Macrothink

Zhu, W., Sosik, J. J., Riggio, R. E., \& Yang, B. (2012). Relationships between transformational and active transactional leadership and followers' organizational identification: The role of psychological empowerment. Journal of Behavioral and Applied Management, 13(3), 186.

\section{Appendix 1. Rule of Thumb for Understanding Size of Correlation Coefficient}

\begin{tabular}{|c|l|}
\hline Size of Correlation & \multicolumn{1}{|c|}{ Interpretation } \\
\hline .90 to $1.00(-.90$ to -1.00$)$ & Very high positive (negative) correlation \\
\hline .70 to $.90(-.70$ to -.90$)$ & High positive (negative) correlation \\
\hline .50 to $.70(-.50$ to -.70$)$ & Moderate positive (negative) correlation \\
\hline .30 to $.50(-.30$ to -.50$)$ & Low positive (negative) correlation \\
\hline .00 to $.30(.00$ to -.30$)$ & Little if any correlation \\
\hline
\end{tabular}

Source: Hinklen et al, (2003). 